\section{EMBRYARIDDLE}

Aeronautical University

SCHOLARLY COMMONS
Journal of Aviation/Aerospace

Education \& Research

Volume 11

Number 1 JAAER Fall 2001

Article 3

Fall 2001

\title{
Arriving at Consensus: Airport/Aviation Administration Advice Provided to Airport Managers by State Aeronautic Agencies
}

Robert W. Kaps

David A. NewMyer

newmyer@siu.edu

Follow this and additional works at: https://commons.erau.edu/jaaer

\section{Scholarly Commons Citation}

Kaps, R. W., \& NewMyer, D. A. (2001). Arriving at Consensus: Airport/Aviation Administration Advice Provided to Airport Managers by State Aeronautic Agencies. Journal of Aviation/Aerospace Education \& Research, 11(1). https://doi.org/10.15394/jaaer.2001.1288

This Article is brought to you for free and open access by the Journals at Scholarly Commons. It has been accepted for inclusion in Journal of Aviation/Aerospace Education \& Research by an authorized administrator of Scholarly Commons. For more information, please contact commons@erau.edu. 


\title{
ARRIVING AT CONSENSUS: AIRPORT/AVIATION ADMINISTRATION ADVICE PROVIDED TO AIRPORT MANAGERS BY STATE AERONAUTIC AGENCIES
}

\author{
Robert W. Kaps and David A. NewMyer
}

\begin{abstract}
Recently a study was undertaken to determine the depth of information provided to small airport managers throughout the United States by State Aeronautical agencies. The study centered on efforts to provide formal, written advice to airport managers about airport and aviation administration matters. For the purpose of the study, advice is considered as material provided to airports exclusive of regulatory codes and rules. More specifically, such advice provides airport managers with valuable insight on how to effectively manage various aspects of airport operations.

The survey material is concerned with a broad range of indigenous airport topics dealing with subject matter from General Aviation Airport Operations to Storm water compliance, and a host of topics in between. The many topics addressed in the state documents that were found in the survey were then compared with two key aviation industry sources of information to arrive at arecommended list of topics for inclusion in ANY airport management handbook for use in any state.

The genesis of the study and report was a grant received by Southern Illinois University Carbondale from the Illinois Department of Transportation, Division of Aeronautics. The goal of the grant was to develop and prepare a "small airport manager handbook" for smaller non-hub airports in Illinois.

Due to the varying nature of laws and regulations concerning airport management and operations from state to state, state aeronautical agencies are in the best position to provide small airport managers with much needed and necessary information on the totality of management functions. However, not all states aeronautical agencies have the human or financial resources to author a comprehensive guide to small airport management. This study found that, at the time the survey was accomplished, only nine states provided some form of advice to airport managers.

\section{INTRODUCTION: PURPOSE OF THE STUDY}

Working under a grant from the Illinois Department of Transportation to develop a handbook for managers and commissioners of small airports in the State of Illinois, a study was undertaken to determine the number of state agencies providing such information. Specifically the study sought to determine the number of states providing handbook information and, secondly to categorize information contained therein.

Once accomplished the study moved to evaluating the overall state submissions with reference to key sources of airport management information. This latter effort led to comparing and contrasting supplied information against industry training devices suggested by the American Association of Airport Executives (AAAE), Accreditation Manual and a leading textbook, Airport Management and

\section{Planning ( $3^{\text {rd }}$ edition) by Alexander Wells.}

\section{METHODOLOGY}

The data collection portion of the study centered on a telephone survey of each state aeronautic agency. Inquiry concentrated on one particular theme, the existence of an airport management handbook. Thus the survey asked only one question, "does your agency distribute some type of 'airport managers handbook' to airport managers to aid in the day-to-day operation of their airports?" When response to the question was affirmative, the state respondent was requested to provide a copy of the handbook. If telephone contact could not be made, or if the representative of the state agency required a formal request to provide information, a letter, attachment $\mathrm{A}$, was furnished. All telephone surveys and resultant mail requests were completed within a three-week period, and all respondent
\end{abstract}


information was received and recorded within five weeks of the original survey.

Upon receipt of all tendered documents, an analysis of information contained in each manuscript was undertaken. Each was scrutinized for information and subject content highlighted as topical. This characterization was determined by selecting and utilizing a keyword topic search of information provided through the fourth level of document organization. Any topic or topics covered at the fourth level or higher was deemed "important." Identified subject matter comprised a matrix of topics used for comparison methods.

Four basic categories were used to summarize the data from this study and the following article is prepared using these categories. First, a listing of those states providing formal written advice to airport managers is provided. Next, an examination of the general types of advice provided by each state is summarized. Third, a determination is made whether the information is categorical or comprehensive. Categorical advice is information provided on obtaining select options such as Federal Aviation Administration Airport Improvement Program Funds. Whereas comprehensive in nature covers subjects across a broad range of topics (e.g. summary of applicable state laws, lease topics, hazardous material handling, etc).

\section{RESULTS}

All states aviation agencies were contacted either by telephone or via mail communication. These agencies represent the entirety of the population under scrutiny. Of the fifty contacted, forty-three or $86 \%$ responded either affirmatively or negatively to the question of whether the state had a manual source of advice information. Of the forty-three, only nine indicated some model of formal advice is provided to airport managers.

The range of advice proffered differed from state to state, however, heterogeneity of topical substance existed. Eight of the states responding provided copies of written advice or manuals while one submitted a videotape used in the conveyance of manual material to airport managers. The eight manual returns were examined for subject matter relevant to airport operations through four levels of each documents structural organization. In the specific case of the video tape presentation, sound bites were extracted pursuant to information coinciding with citations from the previous eight hard article submissions
In addition to the state study, a literature review was undertaken to determine key sources of airport management information available. Using keyword search methods of internet, library and other reference sources two authoritative works consistently recurred, the American Association of Airport Executives (AAAE), Accreditation Manual, authored by Stephen Quilty, and a leading textbook, Airport Management and Planning ( $3^{\text {rd }}$ edition) by Alexander Wells.

Both these sources are representative of airport information as the AAAE Accreditation Manual is the key study source for those preparing for the certified Airport Executives written examination, while the Wells book is used as a key material source for that examination.

As with the state provided manuals, the two reference sources were keyword searched up to and including the fourth level of headings and subheading in each section.

The study then turns to specific topics within each handbook or document provided on a state by state basis. This information is summarized by listing the major headings contained in each formal written policy provide by participating states. Lastly, a comparison is made between the advice provided by the states in comparison to that provided by the selected two key national sources. Conclusions were then drawn about overall key topics among all sources.

The subject matter of each of the eight documents and videotape vary in their approach to information dissemination. Some provide general advice covering a certain category or topic (such as advice only directed to obtaining Federal Aviation Administration Airport Improvement funds), while other are more comprehensive on pecuniary and legal state issues such as summary applications of state law, lease arrangements and taxes. Results were tabulated and became the foundation for comparison.

Sixty-seven individualized concerns were identified from the keyword search. Of these, ten were found to be state specific and, although included in the totality of related subject matter in broad reference, were systematically eliminated for the total indexing used for the survey subject matter. These listings, excluding the state specific subject matter, are contained in Appendices A \& B under the category of "Subject Matter." Table 1 identifies those state specific categories that have been deleted from Appendix A \& B "Subject Matter". 
Table 1 State Specific Advice and State Providing Information

\begin{tabular}{|l|c|c|c|c|c|c|c|c|c|}
\hline Category State $\Rightarrow$ & WI & IN & FL & VA & TX & ND & OH & MA & NM \\
\hline Aircraft Licensing & & & & $\mathrm{X}$ & & & & & $\mathrm{X}$ \\
Airport Rules \& Regulations & & & & & $\mathrm{X}$ & $\mathrm{X}$ & $\mathrm{X}$ & & \\
Annual State Airport Inspections & & $\mathrm{X}$ & & & & $\mathrm{X}$ & $\mathrm{X}$ & & \\
Daily Airport Inspection Requirements & & $\mathrm{X}$ & & & & & & & \\
Florida Airport Statistics & & & $\mathrm{X}$ & & & & & & \\
Florida DOT Specific & & $\mathrm{X}$ & $\mathrm{X}$ & & & & & & \\
Indiana DOT Specific & & & & & & & \\
State Economic Information & $\mathrm{X}$ & & & & & & & & \\
State Statistical Information & $\mathrm{X}$ & & & & & & & & \\
State Taxes & & & & $\mathrm{X}$ & & $\mathrm{X}$ & $\mathrm{X}$ & & \\
\hline
\end{tabular}

In some cases the introduction to each states manual forms a basis for the type information the manual contains. A brief description of each follows:

Florida. The purpose of the Florida Guide to Airport Administration is to provide Florida airport managers with comprehensive information about all aspects of general aviation airport management, including state-specific rules and regulation.

Indiana. The Indiana Department of Transportation, Division of Intermodal Transportation, Aeronautics section's Airport Inspections Manual provides in formation concerning airport standards and specification included in state initiated airport inspections.

Massachusetts. The Massachusetts Aeronautics Commission prepared videotape entitled, How to Apply for Airport Grants. The video describes methods of application, necessary requirements, responsibilities and commitments required to apply for and receive federal and state airport grants.

New Mexico. The New Mexico Airports Manager's Handbook addresses the diverse need of the airport user, the constantly changing regulations, and the underlying need to perform all aviation activities in a safe and consistent manner. The handbook is designed to help airport managers identify strong points in their operation, as well as those that may require improvement.

Texas. The identified purpose of the Texas Airport Management Handbook is to create a single reference document that will address the most common problems facing general aviation airport managers.

Virginia. The Virginia Department of Aviation's Airport Sponsor Information provides discussion on topics of aviation law, airport regulations, and financial aid to airports specific to the Commonwealth of Virginia.

Wisconsin. The intent of the Wisconsin Guide to Airport Administration is to provide state airport managers with comprehensive information about all aspects of general aviation airport management, including state specific rules and regulations.

Table 2 identifies the particular states submitting documentary and video information and the type of advice contained, either comprehensive or categorical.

Table 2 State Agencies Submitting Information and the Type of Advice contained in Each

\begin{tabular}{|l|l|l|}
\hline \multicolumn{1}{|c|}{ State } & Type of Advice & \multicolumn{1}{c|}{ Topics } \\
\hline Florida & Comprehensive & Overall Airport/Aviation Administration \\
Indiana & Categorical & Airport Inspections/Maintenance \\
Massachusetts & Categorical & Grant Applications \\
New Mexico & Categorical & Rules/Regulations, Line Service Ops. \& Airport Inspections/Maintenance \\
North Dakota & Comprehensive & Overall Airport/Aviation Administration \\
Ohio & Comprehensive & Overall Airport/Aviation Administration \\
Texas & Comprehensive & Overall Airport/Aviation Administration \\
Virginia & Comprehensive & Overall Airport/Aviation Administration \\
Wisconsin & Comprehensive & Overall Airport/Aviation Administration \\
\hline
\end{tabular}


Fifty-seven universal categories make up the total number of identified themes contained in state manuals. A total of 513 collective responses were indicated by the nine participating states (Appendix B). Table 3 indicates the number of times each state manual had a category coinciding with one of the fifty-seven identified in the key word search. As can be discerned, the state of Wisconsin addressed a little more than fifty-two percent of the keyword searched subject matter while Maine addressed only four of the issues in their manual.

Table 3 Total Advice categories Identified by Participating States

\begin{tabular}{|r|c|c|c|c|c|c|c|c|c|}
\hline Categories State $\Rightarrow$ & WI & IN & FL & VA & TX & ND & OH & MA & NM \\
\hline \# of subjects coinciding with 57 identified & 30 & 7 & 29 & 17 & 17 & 15 & 16 & 4 & 7 \\
Percent of Total Categories & 52.6 & 12.2 & 50.8 & 29.8 & 29.8 & 26.3 & 28.0 & 7.0 & 12.3 \\
\hline
\end{tabular}

The most frequently addressed state airport subject matter related to financial and fiscal categories of airport operation. This coincides with Kaps \& Widdick (1995) who found that airport managers believed the most critical element for a career in airport management is knowledge of financial management.

A capsulated overview of the advise information reveals that $77 \%$ of the survey participants address financial management concerns; $67 \%$ capital issues and $55 \%$ rent and leasehold dealings as a part of their airport advices. Of the top five indicated advice concerns, sixtyfour percent are pecuniary subjects.

Table 4 identifies topical matter where a high consistency of consensus exists as to its inclusion in state advice's.

Table 4 Most Cited Subject Matter In Nine States Advices

\begin{tabular}{|l|c|}
\hline \multicolumn{1}{|c|}{ Most Often Cited Subject Matter } & Frequency \\
\hline Financial Management & 7 \\
Capital Improvements & 6 \\
Rents and Leases & 5 \\
Maintaining and Improving Facilities & 5 \\
Ground Maintenance & 5 \\
\hline
\end{tabular}

In order to have a better grasp on the thoroughness and detail of the advice provided by the states, it is helpful to compare those advices against the two key national sources of written advice for airport and aviation administrators. The two, Alexander Wells' (1996) book entitled Airport Planning and Management ( $3^{\text {rd }}$ ed.), and the American Association of Airport Executives (AAAE) accreditation module are used for this purpose.

The book, Airport Planning and Management, is commonly used for teaching airport courses in many University Aviation Association approved colleges and universities offering specialized degrees in aviation management/administration. As such, it provides students with an introductory insight of the major elements of the planning, managerial and operational process of an airport. According the texts author (Wells, p.vii), it is designed to be supplemented with current applications drawn from the professor's own experiences, timely articles and reports.

The accreditation modules produced by the AAAE are used to train airport managers/administrators concerning the specificity of their vocation. The modules, broken down by airport subject mater, provide a thorough overview of administrative and operational management subjects. Upon completion of a standardized test administered by the AAAE, the submission of a written paper covering an airport related matter, and a prescribed apprenticeship period, a student may be awarded the title of Accredited Airport Executive (AAE). This accreditation is recognized nationally as the mark of a person well versed in the administration of public airport facilities.

Whereas these two compendium are the primary subject texts used in the education of future and existing airport managers, a comparison of the advice given by the states to those each is apropos. Appendix $\mathrm{C}$ compares the 
advice information received from participating states and compares it to subject matter contained in the seminal sources. To make valid comparisons, the indices of the Wells book was used for like mentioned items and the table of contents of each AAE module identified like subject matter.

- Significantly, the totality of information contained in the two training information sources covered $86 \%$ of the state advice offerings. Individually, the modules of the
AAAE were more comprehensive, addressing $79 \%$ of state advice, whereas the Airport Planning and Management book addressed $58 \%$. Of a the total of fifty-seven individualized subject matter items, only eight were void of subject matter coverage by the combined topical indices of the two sources. Table 5 below identifies these and the frequency of identification of these items in the nine state documents. This frequency of mention is a possible measure of the importance of certain topics.

Table 5 Advice Information Not Covered by Training Materials

\begin{tabular}{|l|c|}
\hline \multicolumn{1}{|c|}{ Most Often Sited Subject Matter } & Frequency \\
\hline Airport Zoning & 4 \\
Air Show Operations & 2 \\
Contract Liability & 2 \\
FBO/Line Services & 2 \\
Government Liability & 2 \\
Hazardous Wildlife Attractants & 1 \\
Land Acquisition & 1 \\
Physical Standards & 1 \\
\hline
\end{tabular}

\section{CONCLUSION}

While state aeronautical agencies offer a wide range of advice services to their airports, only nine provide written advice to airport managers. Interestingly, large aviation states such as New York, North Carolina and California failed to indicate any formalized advice being provided to the small airport manager. Of those states providing such advice, six issue comprehensive coverage while the others disseminate categorical information. Of the topics covered $64 \%$ of the total top five categories related to airport pecuniary measures. Specifically, the most identified concern of advices centered on Financial Management followed closely by Capital Improvement and information concerning Rents and Lease.

When comparing the state information to a national "standard", or more specifically to that information disseminated in a vast majority of aviation collegiate classrooms, only eight of the total identified were not covered in their entirety. Specifically, Airport Planning and Management topically addresses sixty-eight percent of the material, while the Accreditation Manual of the American Airport Association Executive (AAAE) topically covers in at least $80 \%$. Combined the two works address $92 \%$ of the topical subject of the nine state advices.

The 14,575 airports of this country, not eligible for federal funding are a key concern of state aeronautical agencies. Not all state agencies, however, have the human or financial resources to author a comprehensive guide to small airport management.

To circumvent this obstacle, it is recommended that those agencies not able to produce their own guides, contact the state agencies identified in this survey to obtain information on the development of such programs. Other organizations such as the Federal Aviation Administration (FAA) and the National Association of State Aviation Officials (NASAO) also provide information helpful to this effort.

Where, however, generic information can be utilized, and this survey indicates that that is precisely what is contained in many of the state advices, it is recommended that each state add the two reference materials contained in this paper to their libraries of references. 
Robert W. Kaps, Ph.D., is an Associate Professor of Aviation Management at Southern Illinois University at Carbondale where he teaches in the Aviation Management baccalaureate and Public Administration Master's programs, with emphasis on airport administration. Prior to joining the Academy, he spent over twenty-two years in the commercial airline industry in various executive positions with both Major and National air carriers.

David A. NewMyer earned a Master of Arts in Metropolitan Studies from Drew University, a Master of Science in Transportation from Northwestern University and Ph.D. in Education Administration and Higher Education from Southern Illinois University, Carbondale. He is a Professor and Chairperson of the Department of Aviation Management and Flight at Southern Illinois University, Carbondale 


\section{REFERENCES}

Florida Department of Transportation, Aviation Office (1997). Florida guide to airport administration. Tallahassee, Florida: Author.

Indiana Department of Transportation, Division of Intermodal Transportation, Aeronautics section, (1995). Airport inspections, a different view, Indianapolis, Indiana: Author

Kaps Robert W. \& Widick, Leland (1995). Educational requirements for a career in airport management: An industry perspective. Journal of Studies in Technical Careers 5-3, Carbondale, IL

Massachusetts Aeronautics commission (1998). How to apply for airport grants [Film]. (Available from Massachusetts Aeronautics commission, 10 Park Plaza, Room 6620, Boston, MA 02116-3966)

New Mexico State Highway and Transportation Department, State Aviation Division \& New Mexico State University, Geographic Applications and Research Laboratory (1994). Airport manager's handbook. Santa Fe, New Mexico: Author

North Dakota Aeronautics commission (1996). North Dakota airport manager's manual. Bismarck, North Dakota: The airport Planning \& Technology Group, Inc.

Ohio Department of Transportation, Office of Aviation (1998). Ohio airport handbook. Columbus, Ohio: Author

Quilty, S.M. (1998). Accreditation modules. Alexandria, Virginia: American Association of Airport Executives.

Texas Department of Transportation (1991). Texas airport management handbook, a manual for airport owners and operators. Austin, Texas: Author.

Virginia Department of Transportation 1998). Commonwealth of Virginia airport sponsor information. Richmond, Virginia: Author.

Wells, A.T. (1996). Airport planning and management ( $3^{\text {rd }}$ ed.). New York: McGraw-Hill

Wisconsin Department of Transportation, Bureau of Aeronautics (1994). Wisconsin guide to airport administration. Madison, Wisconsin: Author. 


\title{
APPENDIX A
}

\author{
Southern Illinois University \\ College of Applied Science and Arts \\ Department of Aviation Management \& Flight \\ Carbondale, Illinois
}

$<<$ First Name $>><<$ Last Name $>>$

$<<$ Date $>$

$<<$ Job Title $>>$

$<<$ Company $>>$

$<$ <Address $>>$

$<<$ City $>><<$ State $>><<$ Postal Code $>>$

Dear $<<$ Title $>><<$ Last Name $>$ :

Dr. David NewMyer of Southern Illinois University at Carbondale, Department of Aviation Management and Flight is working under the direction of the Illinois Department of Transportation, Division of Aeronautics, to develop handbooks for managers and commissioners of small airport in the State of Illinois.

Has the State of $<<$ State Name $>>$ put together any similar documents? If yes, Dr. NewMyer would like to request copies of such documents. I am interested in learning about what other states have developed to guide small airport managers and commissioners. If you have any questions regarding this request, or require further information, please contact Dr. NewMyer or me. Thank you in advance for your assistance.

Sincerely,

XXXXXXXXX

Graduate Assistant 


\section{APPENDIX B}

Topics Included in State Advices to Airport Managers

\begin{tabular}{|c|c|c|c|c|c|c|c|c|c|}
\hline SUBJECT MATTER $\quad$ STATES $\Rightarrow$ & WI & IND & FLA & VA & TX & ND & OH & MA & $\mathbf{N M}$ \\
\hline ACIP & & & & $\bar{X}$ & $\mathrm{x}$ & & & & \\
\hline AIP \& PFC Funding & & & & & & & & $\mathrm{X}$ & \\
\hline Air Show Operations & & & & & & & $\mathrm{x}$ & $\bar{X}$ & \\
\hline Aircraft Licensing & & & & $\bar{X}$ & & & & & \\
\hline Airport Access & & & & $\mathrm{X}$ & & & & & \\
\hline Airport and Runway Lighting & & $\mathrm{x}$ & & & $\mathrm{X}$ & $\mathrm{X}$ & $\mathbf{X}$ & & \\
\hline Airport Assets & $\mathrm{X}$ & & $\mathbf{x}$ & & & & & & \\
\hline Airport Employee Functions & $\bar{X}$ & & $\mathrm{X}$ & $\mathrm{X}$ & & & & & \\
\hline Airport Funding & & & & $\mathbf{X}$ & $\bar{X}$ & & & & \\
\hline Airport Liability/Aviation Law & $\bar{x}$ & & $\mathrm{X}$ & & & & & & \\
\hline Airport Licensing & & & & $\mathrm{X}$ & & & & & \\
\hline Airport Management/Practices & $\mathrm{X}$ & $\mathrm{X}$ & $\mathrm{X}$ & & & & & & \\
\hline Airport Ownership & $\bar{x}$ & & $\mathbf{X}$ & & & & & & \\
\hline Airport Parking/Hangars & $\mathrm{X}$ & & $\mathbf{x}$ & & $\bar{x}$ & & & & \\
\hline Airport Planning & $\mathrm{X}$ & & $\mathrm{x}$ & & $\mathrm{X}$ & & & & \\
\hline Airport Risk \& Insurance & $\mathbf{X}$ & & $\mathbf{x}$ & & & & & & \\
\hline Airport Rules \& Regulations & & & & & $\mathrm{X}$ & $\mathrm{X}$ & $\mathrm{X}$ & & $\mathrm{X}$ \\
\hline Airport Security & $\mathrm{X}$ & & $\mathrm{x}$ & & & & & & \\
\hline Airport Zoning & & & & $\mathbf{x}$ & $\mathbf{X}$ & $\mathrm{X}$ & $\mathrm{X}$ & & \\
\hline Airspace Obstructions & & & & $\mathbf{X}$ & $\mathrm{X}$ & & & & \\
\hline Airspace Use and Protections & $\bar{X}$ & & $\mathrm{X}$ & $\mathbf{X}$ & $\mathbf{X}$ & & & & \\
\hline Annual State Airport Inspections & & $\mathrm{X}$ & & & & $\mathrm{X}$ & $\mathrm{X}$ & & \\
\hline Capital Improvements & $\bar{X}$ & & $\mathrm{X}$ & $\mathrm{X}$ & $\mathrm{X}$ & $\mathrm{X}$ & $\mathrm{X}$ & & \\
\hline Compatible Land Use & $\mathrm{X}$ & & $\mathrm{x}$ & & & & & & \\
\hline Contract Liability & $\mathrm{X}$ & & $\mathrm{X}$ & & & & & & \\
\hline Daily Airport Inspections & & $\mathrm{x}$ & & & & & & & \\
\hline Economic Impact of Airports & $\mathrm{X}$ & & $\mathrm{x}$ & & & & & & \\
\hline Emergency Operations/Accidents & & & & $\mathrm{X}$ & & $\mathrm{X}$ & $\mathrm{X}$ & & \\
\hline Environment Reg/Impact Studies & & & & & & $\mathrm{x}$ & $\mathrm{x}$ & & \\
\hline FAA History/Current Operations & $\mathrm{X}$ & & $\mathrm{X}$ & & & & & & \\
\hline Facilities \& Property (functions) & $\mathrm{X}$ & & & & & & & & \\
\hline FAR pts. $139 \& 150$ & $\mathrm{X}$ & & $\mathrm{x}$ & & & & & & \\
\hline FBO Liability & $\bar{X}$ & & $\mathrm{X}$ & & & & & & \\
\hline FBO/Line Services & $\mathrm{X}$ & & $\mathrm{X}$ & & & & & & \\
\hline Federal Airport Act & & & & $x$ & & & & & \\
\hline Financial Aid to Airports & & & & $\mathrm{X}$ & & $\mathrm{X}$ & $\mathrm{X}$ & $\mathrm{X}$ & \\
\hline Financial Management & $\mathrm{X}$ & & $\mathbf{x}$ & $\mathrm{X}$ & $\bar{x}$ & $\mathrm{X}$ & $\mathbf{x}$ & $\mathbf{X}$ & \\
\hline Florida DOT & & & $\mathrm{x}$ & & & & & & \\
\hline Florida State Statutes \& Rules & & & $\mathrm{X}$ & & & & & & \\
\hline Ground Maintenance & & & & & $\bar{X}$ & $\mathrm{X}$ & $\bar{x}$ & & $\mathrm{X}$ \\
\hline General Aviation Airports & $\mathrm{X}$ & & $\mathrm{x}$ & & & & & & \\
\hline Government Liability & $\bar{X}$ & & $\mathrm{X}$ & & & & & & \\
\hline Grants \& Loans & & & & $\mathrm{X}$ & & $\mathrm{X}$ & $\mathrm{X}$ & & \\
\hline Ground Maintenance & $\mathrm{X}$ & $\mathrm{x}$ & $\mathrm{x}$ & & $\bar{X}$ & & & & $\bar{x}$ \\
\hline Hazardous Wildlife Attractants & & $\mathrm{X}$ & & & & & & & \\
\hline Indiana DOT & & $\mathrm{X}$ & & & & & & & \\
\hline Introduction to Airports & $\mathrm{X}$ & & $\mathrm{x}$ & & & & & & \\
\hline Issuance of NOTAMs & & $\mathrm{X}$ & & & & $\mathrm{X}$ & $\mathrm{X}$ & & $\mathrm{X}$ \\
\hline Land Acquisition & & & & $\mathrm{X}$ & & & & & \\
\hline Line of Sight & & $\mathrm{X}$ & & & & & & & \\
\hline Maintaining/Improving Facilities & $\mathrm{X}$ & & $\mathrm{x}$ & $\bar{X}$ & $\bar{x}$ & & & & $\mathrm{X}$ \\
\hline Master Plans & $\mathrm{X}$ & & $\mathrm{x}$ & & & & & & \\
\hline Passenger/Visitor services & $\mathrm{X}$ & & $\mathrm{X}$ & & & & & & \\
\hline Petroleum Operations & & & & & & & & & $\mathrm{X}$ \\
\hline
\end{tabular}


Journal of Aviation/Aerospace Education \& Research, Vol. 11, No. 1 [2001], Art. 3

\begin{tabular}{|l|l|l|l|l|l|l|l|l|l|}
\hline Physical Standards & $\mathrm{X}$ & & $\mathrm{X}$ & & & & & & $\mathrm{X}$ \\
\hline Public Relations & $\mathrm{X}$ & & $\mathrm{X}$ & & $\mathrm{X}$ & $\mathrm{X}$ & $\mathrm{X}$ & & \\
\hline Rents \& Leases & $\mathrm{X}$ & & $\mathrm{X}$ & & & & & & \\
\hline Revenue Facilities & & $\mathrm{X}$ & & & $\mathrm{X}$ & & & & \\
\hline Runway Markings & & & & $\mathrm{X}$ & $\mathrm{X}$ & $\mathrm{X}$ & $\mathrm{X}$ & & \\
\hline Safety Procedures & & $\mathrm{X}$ & & & & $\mathrm{X}$ & $\mathrm{X}$ & & \\
\hline Snow Remova/Winter Sa fety & & & & & & $\mathrm{X}$ & $\mathrm{X}$ & & \\
\hline Storm Water Compliance & & & & $\mathrm{X}$ & & $\mathrm{X}$ & $\mathrm{X}$ & & \\
\hline Taxes (paying \& collecting) & & & & & $\mathrm{X}$ & & & & \\
\hline Weather/Atmospheric Effects & & & & & & $\mathrm{X}$ & $\mathrm{X}$ & & $\mathrm{X}$ \\
\hline Why Communities Need Airports & $\mathrm{X}$ & & & & & & & & \\
\hline WI Bureau of Aeronautics & $\mathrm{X}$ & & & & & & & & \\
\hline WI State Statutes & & & &
\end{tabular}




\section{APPENDIX C}

Generic Advices (Excluding State Specific) to Airport Managers v. Wells \& AAAE

\begin{tabular}{|c|c|c|c|c|c|c|c|c|c|c|c|}
\hline SUBJECT STATES $\Rightarrow$ & $\mathbf{W I}$ & IN & FL & $\mathbf{V A}$ & TX & ND & $\mathbf{O H}$ & $\mathbf{M A}$ & $\mathbf{N M}$ & WELLS & $\widehat{A A A E}$ \\
\hline AClP & & & & $\mathrm{X}$ & $\mathbf{X}$ & & & & & & \\
\hline AlP \& PFC Funding & & & & & & & & $\mathrm{X}$ & & & \\
\hline Air Show Operations & & & & & & & $\mathrm{X}$ & $\mathrm{X}$ & & & \\
\hline Airport Access & & & & $\mathrm{x}$ & & & & & & & \\
\hline Airport and Runway Lighting & & $\mathrm{X}$ & & & $\mathrm{X}$ & $\mathrm{X}$ & $\mathrm{x}$ & & & & \\
\hline Airport Assets & $\mathrm{X}$ & & $\mathrm{X}$ & & & & & & & & \\
\hline Airport Employee Functions & $\mathrm{X}$ & & $\mathrm{X}$ & $\mathrm{X}$ & & & & & & & \\
\hline Airport Funding & 1 & & & $\mathrm{X}$ & $\mathrm{X}$ & & & & & & \\
\hline Airport Liability/Aviation Law & $\mathrm{X}$ & & $\bar{x}$ & & & & & & & & \\
\hline Airport Licensing & & & & $\mathrm{X}$ & & & & & & & \\
\hline Airport Management/Practices & $\mathrm{X}$ & $\bar{x}$ & $\bar{x}$ & & & & & & & & \\
\hline Airport Ownership & $\mathrm{X}$ & & $\mathbf{X}$ & & & & & & & & \\
\hline Airport Parking/Hangars & $\mathrm{X}$ & & $\bar{X}$ & & $\bar{x}$ & & & & & & \\
\hline Airport Planning & $\mathrm{X}$ & & $\mathrm{X}$ & & $\mathbf{X}$ & & & & & & \\
\hline Airport Risk \& Insurance & $\mathrm{X}$ & & $\mathrm{X}$ & & & & & & & & \\
\hline Airport Security & $\mathrm{X}$ & & $\bar{X}$ & & & & & & & & \\
\hline Airport Zoning & & & & $\mathrm{X}$ & $\mathrm{X}$ & $X$ & $x$ & & & & \\
\hline Airspace Obstructions & & & & $\mathrm{X}$ & $\mathrm{X}$ & & & & & & \\
\hline Airspace Use and Protections & $\mathrm{x}$ & & $\mathrm{X}$ & $\mathrm{X}$ & $\mathrm{X}$ & & & & & & \\
\hline Capital Improvements & $\mathrm{X}$ & & $\mathrm{X}$ & $\mathrm{X}$ & $\mathrm{X}$ & $\bar{X}$ & $\mathrm{X}$ & & & & \\
\hline Compatible Land Use & $\mathrm{X}$ & & $\mathrm{X}$ & & & & & & & & \\
\hline Contract Liability & $\mathrm{X}$ & & $\mathrm{X}$ & & & & & & & & \\
\hline Economic Impact of Airports & $\mathrm{X}$ & & $\mathrm{X}$ & & & & & & & & \\
\hline Emergency Operations/Accidents & & & & $\mathrm{X}$ & & $\mathrm{X}$ & $\mathrm{X}$ & & & & \\
\hline Environment Reg/Impact Studies & & & & & & $\mathrm{X}$ & $\mathrm{X}$ & & & & \\
\hline FAA History/Current Operations & $\mathrm{X}$ & & $\mathrm{X}$ & & & & & & & & \\
\hline Facilities \& Property (functions) & $\mathrm{x}$ & & & & & & & & & & \\
\hline FAR pts. $139 \& 150$ & $\mathrm{X}$ & & $\mathrm{X}$ & & & & & & & & \\
\hline FBO Liability & $\mathrm{X}$ & & $\mathrm{x}$ & & & & & & & & \\
\hline FBO/Line Services & $\mathrm{X}$ & & $\mathrm{x}$ & & & & & & & & \\
\hline Federal Airport Act & & & & $\mathrm{X}$ & & & & & & & \\
\hline Financial Aid to Airports & & & & $\mathbf{X}$ & & $\mathrm{x}$ & $\mathrm{X}$ & $\mathrm{x}$ & & & \\
\hline Financial Management & $\mathrm{X}$ & & $\mathrm{X}$ & $\mathbf{x}$ & $\mathrm{X}$ & $\mathrm{X}$ & $\mathrm{X}$ & $\mathrm{X}$ & & & \\
\hline Fuel Storage & & & & & $\mathrm{x}$ & $\mathrm{X}$ & $\mathrm{X}$ & & $\mathrm{X}$ & & \\
\hline General Aviation Airports & $\mathrm{X}$ & & $X$ & & & & & & & & \\
\hline Government Liability & $\mathrm{X}$ & & $\mathrm{X}$ & & & & & & & & \\
\hline Grants \& Loans & & & & $\bar{x}$ & & $\mathrm{X}$ & $\mathrm{X}$ & & & & \\
\hline Ground Maintenance & $x$ & $\bar{X}$ & $\mathrm{X}$ & & $\mathrm{x}$ & & & & $\mathrm{X}$ & & \\
\hline Hazardous Wildlife Attractants & & $\mathrm{X}$ & & & & & & & & & \\
\hline Introduction to Airports & $\mathrm{X}$ & & $\mathrm{X}$ & & & & & & & & \\
\hline Issuance of NOTAMs & & $\mathrm{X}$ & & & & $\mathrm{X}$ & $\mathrm{X}$ & & $\mathbf{X}$ & & \\
\hline Land Acquisition & & & & $\mathrm{X}$ & & & & & & & \\
\hline Line of Sight & & $\mathrm{X}$ & & & & & & & & & \\
\hline Maintaining/Improving Facilities & $\mathrm{X}$ & & $\mathrm{X}$ & $\mathrm{X}$ & $\mathrm{X}$ & & & & $\mathrm{X}$ & & \\
\hline Master Plans & $\mathrm{X}$ & & $\mathrm{x}$ & & & & & & & & \\
\hline Passenger/Visitor services & $\mathrm{X}$ & & $\frac{2}{x}$ & & & & & & & & \\
\hline Petroleum Operations & & & & & & & & & $\bar{X}$ & & \\
\hline Physical Standards & & & & & & & & & $\bar{x}$ & & \\
\hline Public Relations & $\mathrm{X}$ & & $\mathrm{X}$ & & & & & & & & \\
\hline Rents \& Leases & $\mathrm{X}$ & & $\mathrm{X}$ & & $\bar{X}$ & $X$ & $\bar{X}$ & & & & \\
\hline Revenue Facilities & $\mathrm{X}$ & & $\mathrm{x}$ & & & & & & & & \\
\hline Runway Markings & & $\mathrm{X}$ & & & $\bar{X}$ & & & & & & \\
\hline Safety Procedures & & & & $\mathrm{X}$ & $\mathrm{X}$ & $\mathrm{x}$ & $\mathrm{X}$ & & & & \\
\hline
\end{tabular}




\begin{tabular}{|l|l|l|l|l|l|l|l|l|l|l|l|}
\hline Snow Removal/Winter Safety & & $\mathrm{X}$ & & & & $\mathrm{X}$ & $\mathrm{X}$ & & & \\
\hline Storm Water Compliance & & & & & & $\mathrm{X}$ & $\mathrm{X}$ & & & \\
\hline Weather/Atmospheric Effects & & & & & $\mathrm{X}$ & & & & & & \\
\hline Why Communities Need Airports & & & & & & $\mathrm{X}$ & $\mathrm{X}$ & & $\mathrm{X}$ & \\
\hline
\end{tabular}

Gray color indicates information included 